\title{
IMPLEMENTASI SISTEM PAKAR BERBASIS WEBSITE UNTUK MENGIDENTIFIKASI HAMA TANAMAN PADI BESERTA PENANGANANNYA
}

\author{
Putri Taqwa Prasetyaningrum ${ }^{1}$, Juwita ${ }^{2}$ \\ ${ }^{1}$ Program Studi Sistem Informasi, ${ }^{2}$ Program Studi Sistem Informasi \\ Jl. Jendral Sudirman No. 40 Modern Cikokol Tangerang, Banten 15117 \\ E-mail :putri@mercubuana-yogya.ac.id ${ }^{1}$,juwita550@gmail.com ${ }^{2}$
}

\begin{abstract}
The development of information technology is indispensable to help in the sharing of areas of life, one of which is in the field of agriculture. The use of information technology in agriculture can help a wide range of issues, especially the need to get information quickly. The farm is currently the largest community in Indonesia is rice that became staples in the country. Local rice production should be maximized by optimizing the farm itself, but problems in the cultivation of rice, one of the largest pest attacking the rice. Pest identification and handling shall be dealt with as quickly as possible in order not to experience a failed harvest.On this research designed an expert system for rice pest identification with method of bayes theorem and forward chaining to handle. The system is built to provide information on the pests of rice and penangananya on the basis of the symptoms that arise. The success of this research is $85 \%$.
\end{abstract}

Keywords: Forward Chaining; Rice Pests; Expert System; Bayes Theorem.

\section{PENDAHULUAN}

Penggunaan teknologi saat ini berkembang pesat di berbagai bidang kehidupan. Sebagian besar masyarakat menggunakannya tidak hanya untuk kepentingan berkomunikasi saja, tetapi juga untuk mendapatkan informasi secara cepat dan efisien. Perkembangan teknologi juga bergerak di bidang pertanian untuk mempermudah mendapatkan informasi secara cepat dan efisien.

Pertanian adalah juga suatu jenis produksi yang berlandaskan pertumbuhan tumbuh-tumbuhan dan hewan. Adapula yang mengemukakan bahwa pertanian adalah kegiatan manusia mengelola lahan melalui proses produksi biologis tumbuhan dan hewan untuk kesejahteraan umat manusia, termasuk kegiatan ekstraktif yang selektif yang tidak merusak kelestarian lingkungan (Fatah, 2006).

Padi (bahasa latin: Orza sativa L.) merupakan tanaman yang menjadi komoditas bagi sebagian besar petani di Indonesia. Padi berperan penting terhadap ketersedian beras di Indonesia. Budidaya dan meningkatkan hasil dari pertanian khusunya padi sangat perlu dan wajib dilakukan untuk memenuhi kebutuhan pokok 
yaitu kebutuhan pangan yang menjadi penentu status gizi di Indonesia. Hama dan penyakit khususnya tanaman padi menjadi masalah yang pasti dihadapi oleh petani Indonesia. Untuk melindungi tanaman dari serangan hama dan penyakit, sebaikanya kita mengenal lingkungan hidup di sekitar tanaman, daur hidup hama dan penyakit, daur hidup musuh alami, keadaan cuaca yang mendukung perkembangan hama dan penyakit, musuh alaminya, dan pergantian tanaman inang baik yang dipelihara maupun liar (Pracaya, 2008).

Dampak hama padi seperti tikus, wereng, walang sangit dan hama lainya sering dirasakan oleh petani, yang paling parah adalah terjadinya gagal panen. Dari permaslaahn diatas, maka diperlukan suatu suatu sitem secara komputerisasi akan membantu dalam pengambilan keputusan yang lebih mudah dan cepat, oleh karena itu perlu adanya penelitian untuk mengakusisi kemampuan pakar secara komputerisasi. Menurut Sukadi (2013), diagnosa hama padi dengan metode forward chaining untuk menentukan jenis hama atau penyakit yang menyerang tanaman padi dan cara mengatasi permasalah dari hama atau penyakit yang telah diketahui sebelumnya. Dalam mendiagnosa hama padi dan memberikan solusi penangananya menggunakan forward chaining dengan difinisi decision tree (Yulianto,2015). Menurut Fakih (2015), yang melakukan penelitian tentang penyakit padi menggunakan 2 metode yaitu forward chaining dan certainty factor yang menggunakan analisis SWOT. Metode certainty factor dimana jika hipotesis atau gejala yang timbul akan dihitung untuk mencari nilai CF, apabila nilai CF lebih dari 0,5 dari penyakit yang dipilih maka akan menampilkan penyakit yang menyerang hama padi tersebut (Irwan,2016). Selain itu penelitian yang dilakukan oleh Ryani (2015), menggunakan Metode bayes dan forward chaining untuk megetahui mengatasi penyakit ikan Koi.

Penelitian ini bertujuan untuk mengakusisi kemampuan pakar dalam menentukan hama tanaman padi beserta penanganannya dengan mengimplementasikan metode bayes dan forward chaining.

\section{METODE PENELITIAN}

\section{Alur Penelitian}

Adapun jalan penelitian dengan teknik pengumpulan data sebagai berikut :

1. Studi Kepustakaan

Studi kepustakaan dilakukan untuk medapatkan data ataupun pengetahuan dengan sumber berupa buku atau sumber lainya secara tertulis. Studi ini dimulai dengan mengumpulkan data-data hama penyakit padi beserta gejalanya di mana gejala dari 
setiap penyakit didata dan disiapkan. Selain data penelitian ada juga sumber informasi seperti metode dan refrensi lainya.

\section{Wawancara}

Wawancara dalam sesi ini untuk medapatkan data dari setiap gejala yang di dapatkan dari buku, serta validasi data yang berhubungan dengan perhitungan dalam menentukan hama padi dan penangananya. Dalam wawancara ini penulis mewancarai Kepala Kelompok Tani di Desa Lengkong, Donomulyo, Nanggulan, Kulon Progo. Adapun jalanya penelitian dapat dilihat pada gambar berikut :

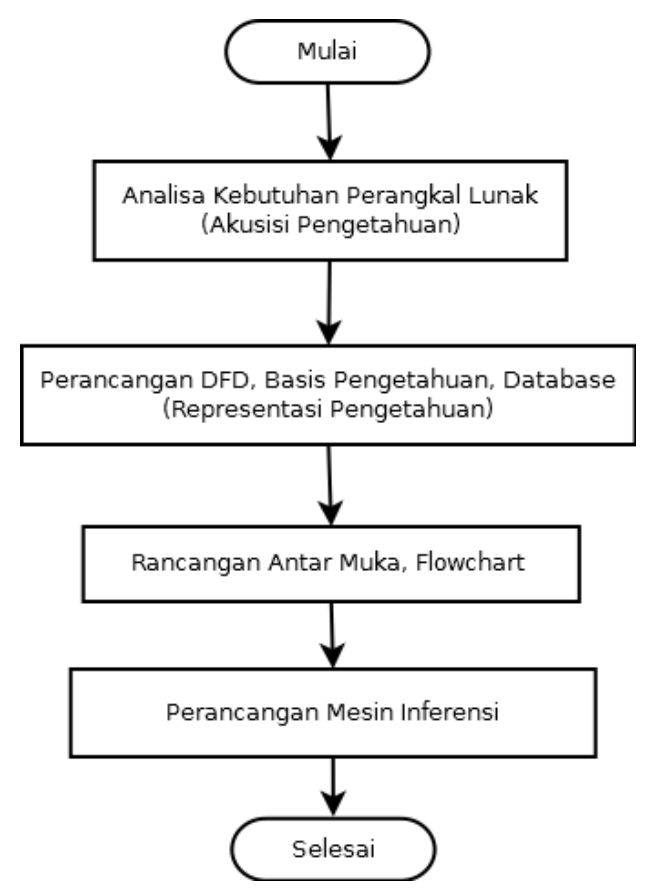

Gambar 1 Jalan Penelitian

\section{Akusisi Pengentahuan}

Akusisi pengetahuan atau analisa kebutuhan perangkat lunak merupakan kegiatan untuk mencari dan mengumpulkan data untuk keperluan perangkat lunak yang meliputi :

1. Analisis Kebutuhan Masukan

Adapun masukan yang diberikan oleh pakar untuk kebutuhan penelitian adalah sebagai berikut :

a. Data penting seperti macam - macam hama dan gejala yang ditimbukan dari masing - masing hama beseta penangananya.

b. Bobot dari tiap evidence terhadap hipotesa yang belum ada dalam sistem.

c. Data yang didapatkan dihitung dengan aturan perhitungan dan disesuaikan dengan perhitungan pakar. 
d. Dari ketiga poin tersebut, akan digunakan sebagai pengetahuan yang diterapkan dalam deteksi hama padi dan penangananya.

2. Analisis Kebutuhan Proses

Sistem ini melakukan penalaran untuk menentukan hama penyakit padi beserta penangananya dengan menggunakan 2 metode yaitu metode bayes dan forward chaining. Proses dari sistem ini memiliki 2 tahap peprosesan yaitu dengan metode bayes untuk mendeteksi hama dan forward chaining untuk cara mengatasi hama tersebut dengan memasukan gejala yang terjadi pada hami yang diteliti.

3. Analisis Kebutuhan Keluaran

Data atau hasil yang akan dikeluarkan dari sistem ini adalah berupa hama padi yang menyerang beserta bagaimana cara menangani hama tersebut dimana hasil tersebut didapatka dari beberapa gejala yang memiliki bobot. Dari bobot itu dihitung dengan metode bayes dan forward chaining untuk menampilkan hasil.

\section{Perancangan Basis Pengetahuan}

Perancangan database merupakan proses untuk menentukan isi data yang dibutuhkan untuk mendukung rancangan sistem. Model rancangan database yang dibangun adalah model relationship dimana seluruh tabel saling berhubungan satu dengan yang lain.

\section{Entity Relation Diagram (ERD)}

Entity Relation Diagram (ERD) pada sistem pada sistem pakar identifikasi hama padi dan penangannya, ditampilkan pada gambar berikut :

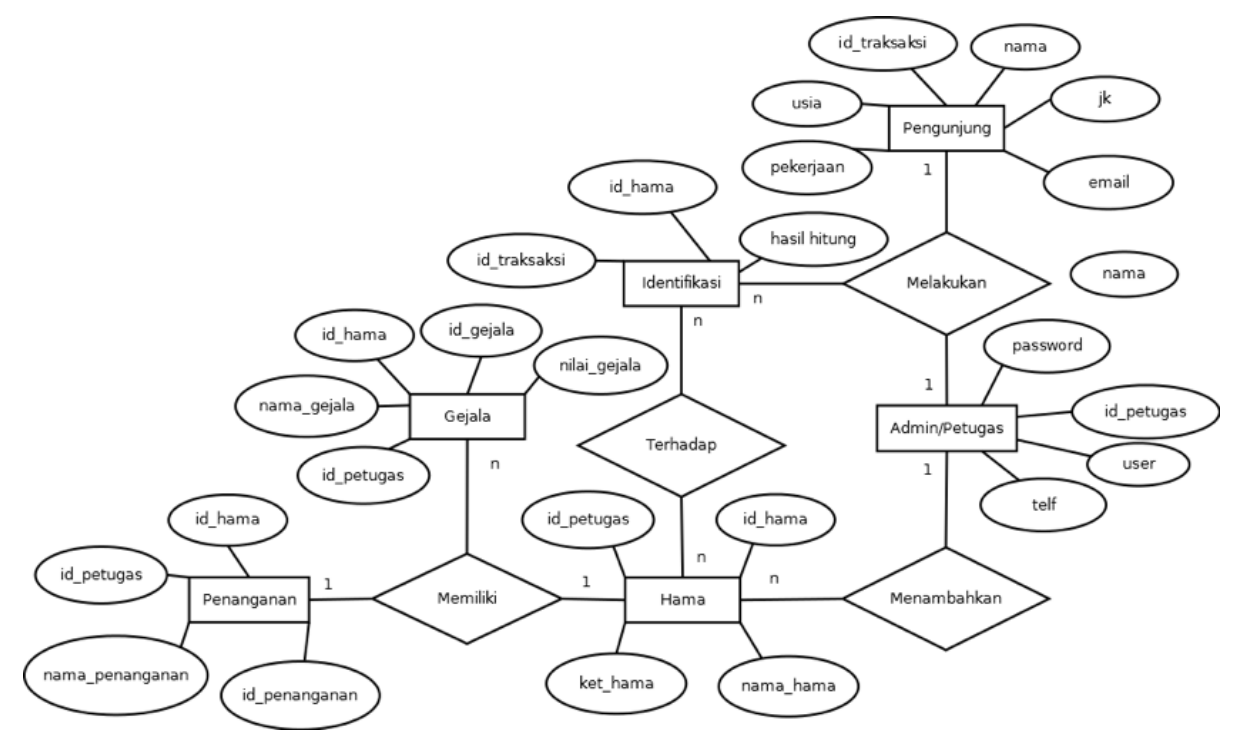

Gambar 2. ERD 


\section{Perancangan DFD}

Data Flow Diagram merupakan diagram alir data yang menggambarkan bagaimana data diproses oleh sistem. Selain itu Data Flow Diagram (DFD) mengambarkan notasi-notasi aliran data di dalam sistem dapat dilihat pada gambar berikut:

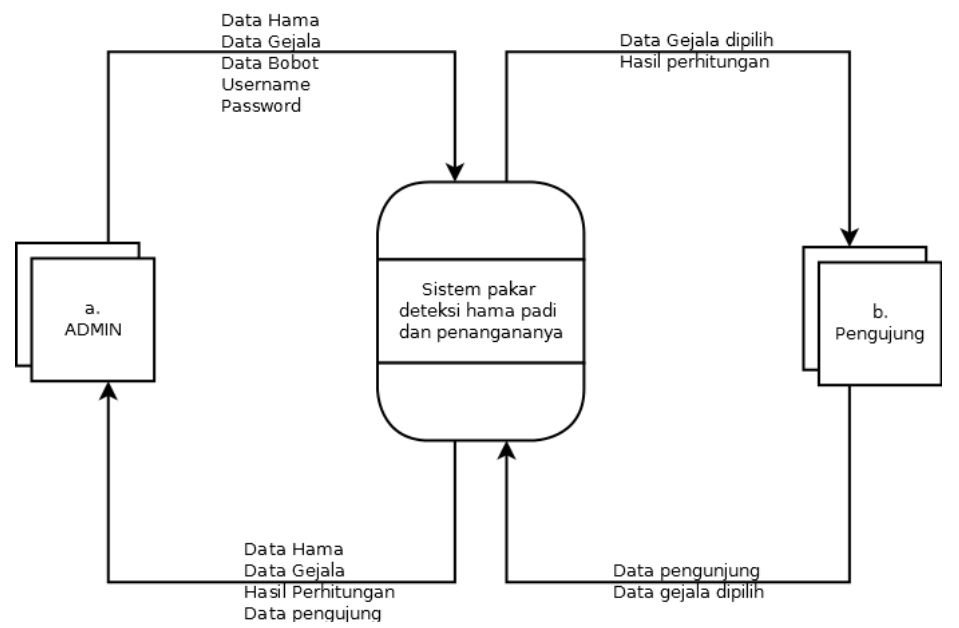

Gambar 3. Diagram Konteks

\section{Relasi Database}

Relasi database dalam sistem informasi deteksi hama penyakit padi dan penangannya ditampilkan pada gambar berikut :

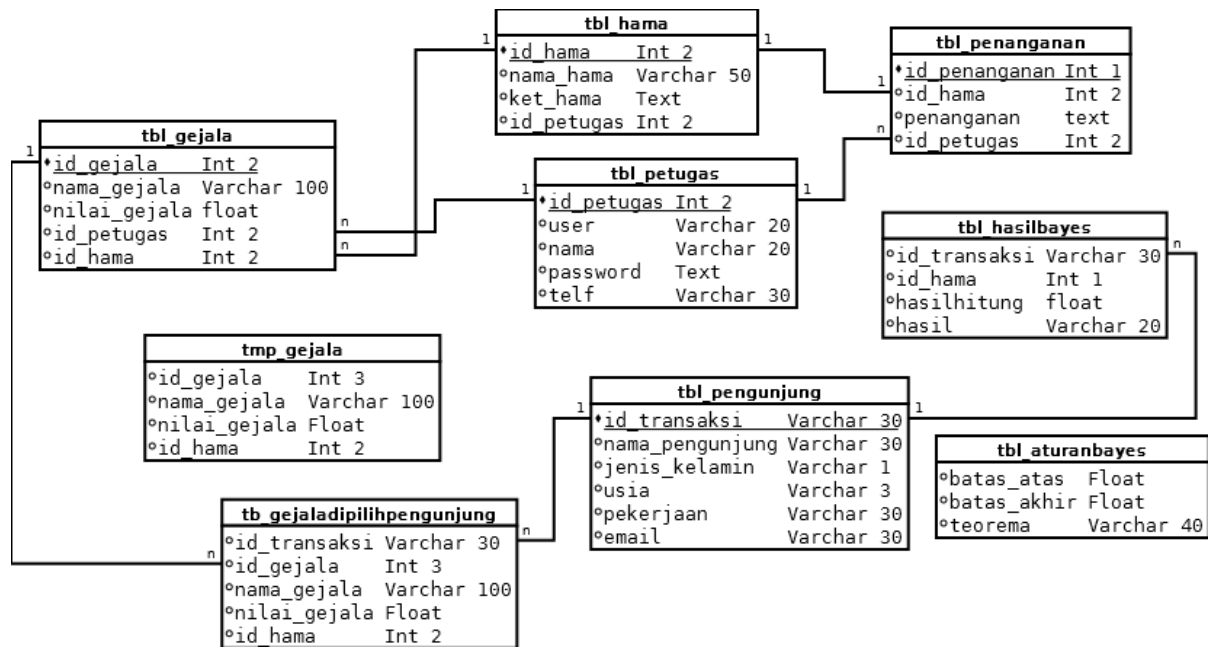

Gambar 4. Relasi Database

\section{Iferensi Pengetahuan}

Dalam Perancangan sistem pakar ini menggunakan metode teorema bayes dan forward chaining. Teorema bayes dimulai dari mencari nilai semesta total bobot gejala dari tiap penyakit lalu menghitung nilai semesta $\mathrm{P}(\mathrm{Hi})$ dilanjukan dengan menghitung probabilitas $(\mathrm{H})$ tanpa memandang evidence apapun barulah mencari nilai P (Hi $\mid \mathrm{E})$ dan langkah terakhir menjumlahkan nilai bayes. 
Perancangan sistem pakar yang menggunakan teorema bayes dan forward chaining ini menggunakan langkah - langkah sebagai berikut :

a. Langkah Ke 1 Perhitungan Bayes

Langkah ke 3 ini menjelaskan bagaimana teorema bayes di implementasikan untuk menentukan hama padi. Langkah perhitunganya sebagai berikut :

- Mencari nilai semesta

Mencari nilai semesta yaitu menjumlahkan hipotesa dari nilai gejala yang dihitung sebagai berikut :

$$
\longdiv { \sum _ { G 5 } ^ { 7 } \mathrm { K } = 1 = \mathrm { G } 1 + \mathrm { G } 2 + \mathrm { G } 3 + \mathrm { G } 4 + \mathrm { G } 5 }
$$

- Mencari nilai semesta P(Hi)

Mencari nilai $\mathrm{P}(\mathrm{Hi})$ yaitu mencari nilai dari setiap gejala yang dibagi dengan nilai semesta, perhitunganya sebagai berikut :

Rumus :

$$
P(H 1,2, \ldots n)=\frac{H 1, H 2, \ldots . n}{\sum_{k=1}^{P 1}}
$$

- Menghitung probabilitas $\mathrm{H}$ tanpa memandang evidence apapun

Menghitung probabilitas $\mathrm{H}$ tanpa memandang evidence apapun dicari jika semua nilai $\mathrm{P}(\mathrm{Hi})$ sudah diketahui semua. Perhitungan dalam langkah ini adalah sebagai berikut :

$$
\sum_{\text {Gro1 }}^{P 01}=P(H i) \times P(E \mid H i-n)
$$

- Mencari nilai P(Hi|E)

$$
\mathrm{P}(\mathrm{H} \mid \mathrm{E})=\frac{p(E \mid H) x p(H)}{p(E)}
$$

- Menghitung total nilai bayes

Apabila nilai $\mathrm{P}(\mathrm{Hi} \mid \mathrm{E})$ sudah diketahui, jumlahkan seluruh nilai untuk menemukan nilai bayesnya dengan rumus berikut : $\sum_{k=1}^{P 1}$ Bayes $=$ Bayes $1+$ Bayes $2+$ Bayes $3+,,,,,, n$

- Mencocokan dengan nilai bayes

Mencocokan dengan nilai bayes bertujuan untuk mengetahui kelas dari nilai tersebut, untuk kelas yang dimaksud dapat dilihat pada tabel berikut : 


\begin{tabular}{|c|c|l|}
\hline No & Nilai Bayes & Teorema Bayes \\
\hline 1. & $0.0-0.2$ & Tidak Ada \\
\hline 2. & $0.3-0.4$ & Mungkin \\
\hline 3. & $0.5-0.6$ & Kemungkinan Besar \\
\hline 4. & $0.7-0.8$ & Hampir Pasti \\
\hline 5. & $0.9-1.0$ & Pasti \\
\hline
\end{tabular}

Maka identifikasi hama yang dihasilkan adalah pasti terserang hama Tugro.

b. Langkah Ke 4 Forward Chaining

Forward chaining digunakan untuk menentukan penanganan hama yang telah terdeteksi. Data penanganan yang didapatkan dari pakar adalah penanganan setiap hama, tidak ada kobinasi hama dengan penanganan yang berbeda.

\section{Perancangan Antar Muka}

Perancangan antarmuka sangat diperlukan untuk mempermudah penggunaan dari sistem deteksi hama padi beserta penanganannya. Dalam sistem ini dibagi menjadi 2 antar muka yaitu sebagai admin dan pengunjung.

1. Rancangan Halaman Utama Pengunjung (Front End)

Rancangan halaman utama untuk pengujung dapat dilihat pada gambar berikut :

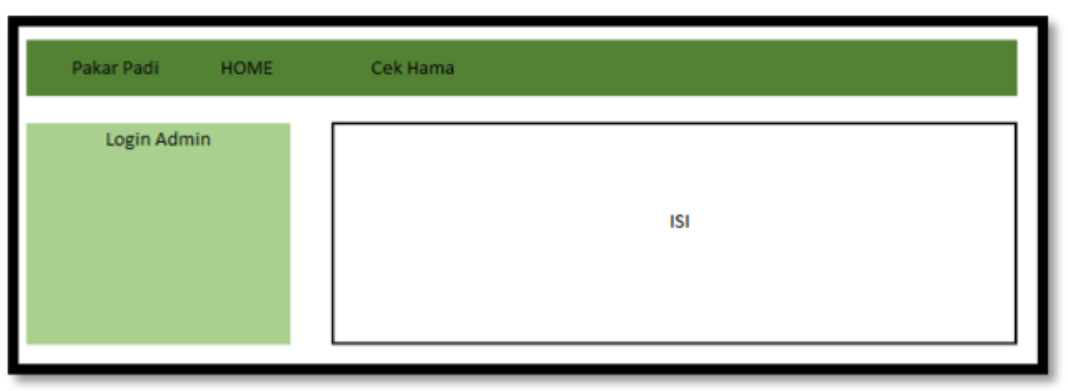

Gambar 5. Halaman Utama Pengunjung

2. Rancangan Halaman Admin (Back End)

Rancangan halaman admin merupakan halaman dimana admin/petugas dapat melakukan login. Halaman ini dapat dilihat pada gambar berikut :

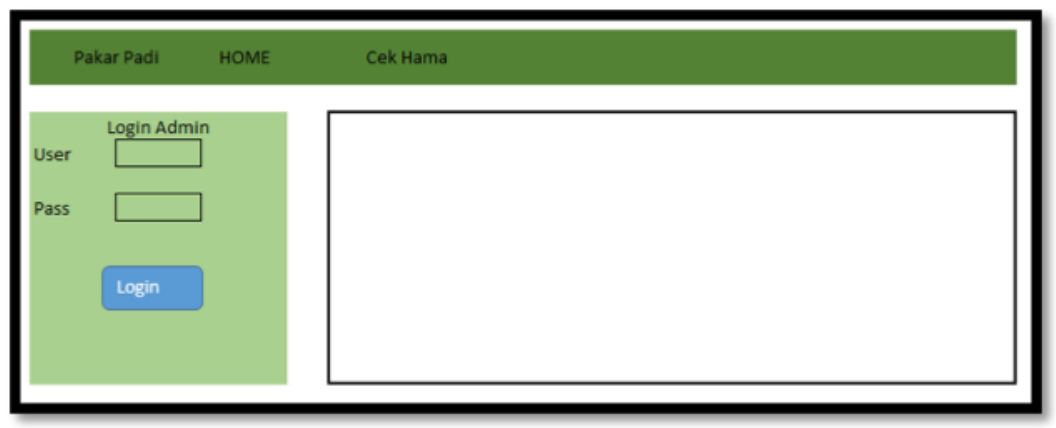

Gambar 6.Halaman Login Admin 


\section{PEMBAHASAN}

Hasil pengujian yang dilakukan pada sistem pakar untuk identifikasi hama padi dan penanganannya menujukan ujuk kerja sistem yang sesuai dengan keterangan yang didapat dari pakar. Berikut data identifikasi hama padi yang didapatkan dari hasil kuisioner kepada petani yang dilakukan di desa Lengkong, Donumulyo, Nanggulan, Kulon Progo. Data pengujian dapat dilihat pada tabel berikut :

Tabel 2. Hasil pakar yang di Desa Lengkong, Kulon Progo

\begin{tabular}{|c|c|c|c|c|}
\hline NO & Nama & Umur & Gejala & Hasil \\
\hline 1 & Mujirah & 35 & G16,G17, dan G18 & P5 \\
\hline 2 & Kasan Dimejo & 78 & G22, G23, G24, G25 dan G26 & P7 \\
\hline 3 & Saniem & 45 & G05, G06, G07, G08, G021, dan G023 & P2 \\
\hline 4 & Nurjanah & 38 & G21, G22, G23, G24 dan G25 & P7 \\
\hline 5 & Paryanti & 38 & G13, G14, dan G15 & P4 \\
\hline 6 & Jemino & 75 & G04, G05, G06, G08, dan G09 & P3 \\
\hline 7 & Pawiro Loso & 77 & G16, G17, G18, G19, G20 dan G21 & P5 \\
\hline 8 & Parjio & 37 & G01, G02, dan G03 & P1 \\
\hline 9 & Poniman & 41 & G13, G14 dan G14 & P4 \\
\hline 10 & Ngadiman & 41 & G19, G20, dan G21 & P6 \\
\hline 11 & Tukiyo & 90 & $\mathrm{G} 22, \mathrm{G} 23, \mathrm{G} 24$ dan G25 & P7 \\
\hline 12 & Wakir & 65 & G22, G23, G24 dan G25 & P7 \\
\hline 13 & Joyo Ngadiyo & 75 & G01, G02, G03 dan G21 & P1 \\
\hline 14 & Jirah & 60 & $\mathrm{G} 22, \mathrm{G} 23, \mathrm{G} 24, \mathrm{G} 25$ dan G26 & P7 \\
\hline 15 & Watini & 49 & G04, G05, G06, G08, dan G09 & P2 \\
\hline 16 & Sajiman & 55 & G05, G10, G11, dan G12 & P3 \\
\hline 17 & Kliyem & 55 & G01, G02, G03 dan G21 & P1 \\
\hline 18 & Paidin & 45 & G01, G02, G03, G04 dan G21 & P1 \\
\hline 19 & Sutiman & 35 & G19, G20 dan G21 & P6 \\
\hline 20 & Remo & 43 & G17, G18 dan G19 & P5 \\
\hline
\end{tabular}

\section{Hasil Pengujian Program}

Pengujian progam dilakukan setelah selesai tahap pembuatan progam untuk mengetahui kebenaran sistem dalam melakukan perhitungan identifikasi hama padi dan penanganannya. Tahap pengujian ini dilakukan dengan cara menguji tingkat 
kebenaran sistem dalam proses penentuan identifikasi yang sesuai dengan nilai probabilitas dan aturan yang sudah ditentukan sebelumnya. Halaman hitung hasil menampilkan bagaimana sistem tersebut berjalan. Halaman ini dapat dilihat pada gambar berikut :

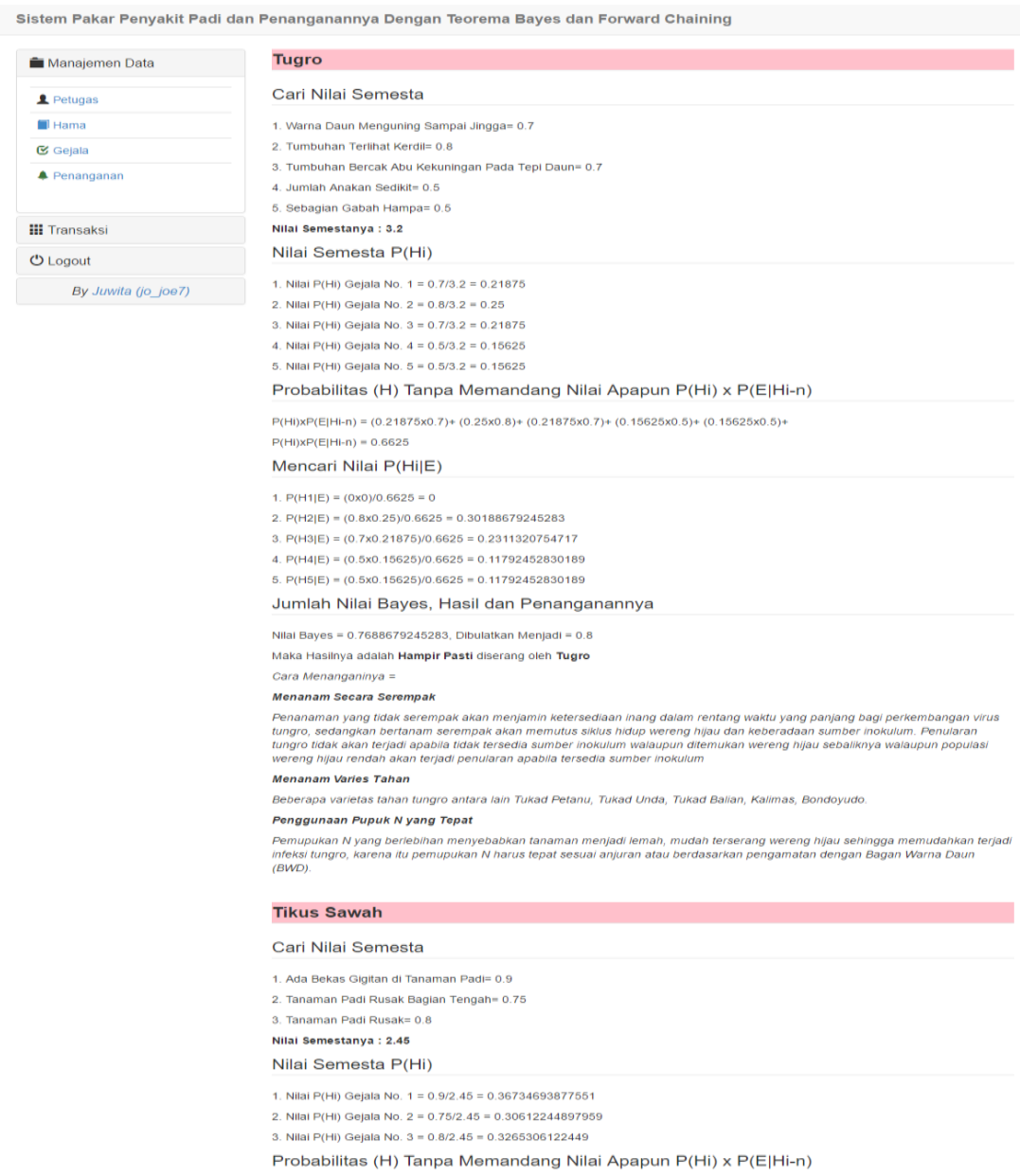

Gambar 7.Halaman Hitung Hasil

\section{Analisis dan Pembahasan}

Analisis dan pembahasan bertujuan untuk menentukan hama yang menyerang tanaman padi dengan menyeleksi gejala yang timbul. Data yang telah didapatkan sebelumnya 7 hama dengan 26 gejala.

Proses identifikasi dengan metode bayes dan forward chaining mengambil sample dari salah satu kuisioner dengan data di tabel berikut :

\begin{tabular}{|l|l|l|l|l|}
\hline 12 & Wakir & 65 & G22, G23, G24 dan G25 & P7 \\
\hline
\end{tabular}

Data yang didapatkan diatas akan dihitung dengan metode bayes dan forward chaining dengan langkah - langkah sebagai berikut :

a. Langkah 1 Permasalah

Daftar hama yang ada dalam sistem adalah sebagai berikut : 
Tabel 3.Hama Padi

\begin{tabular}{|l|l|l|}
\hline NO & KODE & Nama Hama \\
\hline 1 & P1 & Wereng Coklat atau Wereng Hijau \\
\hline 2 & P2 & Penggerek Batang \\
\hline 3 & P3 & Hawar Daun Bakteri \\
\hline 4 & P4 & Walang Sangit \\
\hline 5 & P5 & Keong Mas \\
\hline 6 & P6 & Tikus Sawah \\
\hline 7 & P7 & Tugro \\
\hline
\end{tabular}

Gejala dari hama yang ada dalam sistem adalah sebagai berikut

Tabel 4. Gejala

\begin{tabular}{|c|c|c|}
\hline NO & KODE & Nama Gejala \\
\hline 1 & G01 & Tanaman Layu \\
\hline 2 & G02 & Daun Tua Menguning \\
\hline 3 & G03 & Tanaman Kering Cepat dan Seperti Terbakar \\
\hline 4 & G04 & Ditemukan Adanya Ngengat \\
\hline 5 & G05 & Tunas Mati \\
\hline 6 & G06 & Ujung Daun Ada Yang Bewarna Putih \\
\hline 7 & G07 & Ujung Kering \\
\hline 8 & G08 & Ujung Mudah Ditarik Jika Mati \\
\hline 9 & G09 & Batang Busuk Kehitaman \\
\hline 10 & G10 & Daun Bewarna Hijau Kelabu \\
\hline 11 & G11 & Daun Melipat dan Menggulung \\
\hline 12 & G12 & Timbul Bercak Abu Kekuningan Pada Tepi Daun \\
\hline 13 & G13 & Butir Gabah Tidak Berisi dan Bewarna Hitam \\
\hline 14 & G14 & Beras Berubah Warna dan Mengapur \\
\hline 15 & G15 & Terdapat Anak Walang Sangit (Cecenda/Gulma) \\
\hline 16 & G16 & Ada Bekas Potongan Padi Muda Mengambang \\
\hline 17 & G17 & Terdapat Telur Keong Disawah \\
\hline 18 & G18 & Ditemukan Keong Warna Kuning (Keong Mas) \\
\hline 19 & G19 & Ada Bekas Gigitan di Tanaman Padi \\
\hline 20 & G20 & Tanaman Padi Rusak Bagian Tengah \\
\hline 21 & G21 & Tanaman Padi Rusak \\
\hline 22 & G22 & Warna Daun Menguning Sampai Jingga \\
\hline 23 & G23 & Tumbuhan Terlihat Kerdil \\
\hline 24 & G24 & Tumbuhan Bercak Abu Kekuningan Pada Tepi Daun \\
\hline 25 & G25 & Jumlah Anakan Sedikit \\
\hline 26 & G26 & Sebagian Gabah Hampa \\
\hline
\end{tabular}

Dari hama kode P7 memiliki gejala dengan rule G22, G23, G24, G25, dan G26 dengan nilai probabilitas 1. Dari kode tersebut diketahui bahwa hama Tugro memiliki gejala sebagai berikut : 

a. G22 = Warna Daun Menguning Sampai Jingga
b. $\mathrm{G} 23=$ Tumbuhan Terlihat Kerdil
c. G24 = Tumbuhan Bercak Abu Kekuningan Pada Tepi Daun
d. G25 = Jumlah Anakan Sedikit
e. $\mathrm{G} 26=$ Sebagian Gabah Hampa

b. Langkah 2 Nilai Pakar Terhadap Gejala

Nilai pakar yang telah didapatkan dari pakar terhadap gejala hama Tugro sebagai berikut :
a) $\mathrm{G} 22=0.7$
b) $\mathrm{G} 23=0.8$
c) $\mathrm{G} 24=0.7$
d) $\mathrm{G} 25=0.5$
e) $\mathrm{G} 26=0.5$

c. Langkah Ke 3 Perhitungan Bayes

Langkah ke 3 ini menjelaskan bagaimana teorema bayes di implementasikan untuk menentukan hama padi. Langkah perhitunganya sebagai berikut :

- Mencari nilai semesta

Mencari nilai semesta yaitu menjumlahkan hipotesa dari nilai gejala yang dihitung sebagai berikut :

$$
\begin{aligned}
\sum_{G .5}^{7} \mathrm{~K}=1=\mathrm{G} 1+\mathrm{G} 2 & +\mathrm{G} 3+\mathrm{G} 4+\mathrm{G} 5 \\
& =0.7+0.8+0.7+0.5+0.5 \\
& =3.2
\end{aligned}
$$

- Mencari nilai semesta P(Hi)

Mencari nilai $\mathrm{P}(\mathrm{Hi})$ yaitu mencari nilai dari setiap gejala yang dibagi dengan nilai semesta, perhitunganya sebagai berikut :

Rumus :

$$
\begin{aligned}
& P(H 1,2, \ldots n)=\frac{H 1, H 2, \ldots . n}{\sum_{k=1}^{P 7}} \\
& \mathrm{P}(\mathrm{H} 1)=0.7 / 3.2=0.218 \\
& \mathrm{P}(\mathrm{H} 2)=0.8 / 3.2=0.250 \\
& \mathrm{P}(\mathrm{H} 3)=0.7 / 3.2=0.218 \\
& \mathrm{P}(\mathrm{H} 4)=0.5 / 3.2=0.156 \\
& \mathrm{P}(\mathrm{H} 5)=0.5 / 3.2=0.156
\end{aligned}
$$

- Menghitung probabilitas $\mathrm{H}$ tanpa memandang evidence apapun

Menghitung probabilitas $\mathrm{H}$ tanpa memandang evidence apapun dicari jika semua nilai $\mathrm{P}(\mathrm{Hi})$ sudah diketahui semua. Perhitungan dalam langkah ini adalah sebagai berikut : 
$\sum_{\text {GrO6 }}^{P 07}=P(H i) \times P(E \mid H i-n)$

- $\mathrm{P}(\mathrm{H} 1) \times \mathrm{P}(\mathrm{E} \mid \mathrm{H} 1)=0,218 \times 0,7=0,152$

- $\mathrm{P}(\mathrm{H} 2) \times \mathrm{P}(\mathrm{E} \mid \mathrm{H} 2)=0,250 \times 0,8=0,200$

- $\mathrm{P}(\mathrm{H} 3) \times \mathrm{P}(\mathrm{E} \mid \mathrm{H} 3)=0.218 \times 0,7=0,152$

- $\mathrm{P}(\mathrm{H} 4) \times \mathrm{P}(\mathrm{E} \mid \mathrm{H} 4)=0.156 \times 0,5=0.078$

- $\mathrm{P}(\mathrm{H} 5) \times \mathrm{P}(\mathrm{E} \mid \mathrm{H} 5)=0.156 \times 0,5=0.078$

Total Hipotesa $(\mathrm{H})=0.66$

- Mencari nilai $\mathrm{P}(\mathrm{Hi} \mid \mathrm{E})$

$$
\mathrm{P}(\mathrm{H} \mid \mathrm{E})=\frac{p(E \mid H) x p(H)}{p(E)}
$$

- $\mathrm{P}(\mathrm{H} 1 \mid \mathrm{E})=(0,218 \times 0,7) / 0.66=0,231$

- $\quad \mathrm{P}(\mathrm{H} 2 \mid \mathrm{E})=(0,250 \times 0,8) / 0.66=0,301$

- $\mathrm{P}(\mathrm{H} 3 \mid \mathrm{E})=(0.218 \times 0,7) / 0.66=0,231$

- $\quad \mathrm{P}(\mathrm{H} 4 \mid \mathrm{E})=(0.156 \times 0,5) / 0.66=0,117$

- $\quad \mathrm{P}(\mathrm{H} 5 \mid \mathrm{E})=(0.156 \times 0,5) / 0.66=0,117$

- Menghitung total nilai bayes

Apabila nilai $\quad \mathrm{P}(\mathrm{Hi} \mid \mathrm{E})$ sudah diketahui, jumlahkan seluruh nilai untuk menemukan nilai bayesnya dengan rumus berikut :

$$
\begin{aligned}
\mid \sum_{k=5}^{P 007} \text { Bayes }= & \text { Bayes } 1+\text { Bayes } 2+\text { Bayes } 3+,,,,,, n \\
& =0,231+0,301+0,231+0,117+0,117 \\
& =1
\end{aligned}
$$

Pada kasus awal gejala yang dipilih tidak yaitu gejala dengan keterangan "sebagian gabah hampa" tidak di pilih maka totalnya adalah 0,88 dibulatkan menjadi 0,9 .

- Mencocokan dengan nilai bayes

Mencocokan dengan nilai bayes bertujuan untuk mengetahui kelas dari nilai tersebut, untuk kelas yang dimaksud dapat dilihat pada tabel berikut :

Tabel 5. Aturan Bayes

\begin{tabular}{|c|c|l|}
\hline No & Nilai Bayes & Teorema Bayes \\
\hline 1. & $0.0-0.2$ & Tidak Ada \\
\hline 2. & $0.3-0.4$ & Mungkin \\
\hline 3. & $0.5-0.6$ & Kemungkinan Besar \\
\hline 4. & $0.7-0.8$ & Hampir Pasti \\
\hline 5. & $0.9-1.0$ & Pasti \\
\hline
\end{tabular}

Maka identifikasi hama yang dihasilkan adalah pasti terserang hama Tugro.

c. Langkah Ke 4 Forward Chaining

Forward chaining digunakan untuk menentukan penanganan hama yang telah terdeteksi. Data penanganan yang didapatkan dari pakar adalah 
penanganan setiap hama, tidak ada kobinasi hama dengan penanganan yang berbeda, maka penanganan untuk hama tugro adalah sebagai berikut :

1) Menanam Secara Serempak

Penanaman yang tidak serempak akan menjamin ketersediaan inang dalam rentang waktu yang panjang bagi perkembangan virus tungro, sedangkan bertanam serempak akan memutus siklus hidup wereng hijau dan keberadaan sumber inokulum. Penularan tungro tidak akan terjadi apabila tidak tersedia sumber inokulum walaupun ditemukan wereng hijau sebaliknya walaupun populasi wereng hijau rendah akan terjadi penularan apabila tersedia sumber inokulum

2) Menanam Varies Tahan

Beberapa varietas tahan tungro antara lain Tukad Petanu, Tukad Unda, Tukad Balian, Kalimas, Bondoyudo.

\section{3) Penggunaan Pupuk N yang Tepat}

Pemupukan $\mathrm{N}$ yang berlebihan menyebabkan tanaman menjadi lemah, mudah terserang wereng hijau sehingga memudahkan terjadi infeksi tungro, karena itu pemupukan $\mathrm{N}$ harus tepat sesuai anjuran atau berdasarkan pengamatan dengan Bagan Warna Daun (BWD).

\section{Validasi Hasil}

Validasi hasil bertujuan untuk membandingkan bagaimana hasil kerja sistem identifikasi hama padi dengan hasil yang diberikan oleh pakar. Perbandingan ini dapat dilihat pada gambar berikut :

Tabel 6. Validasi Data

\begin{tabular}{|l|l|l|l|l|l|l|}
\hline NO & \multicolumn{1}{|c|}{ Nama } & Umur & \multicolumn{1}{|c|}{ Hasil Pakar } & Hasil Sistem & \multicolumn{1}{c|}{ Sesuai/Tidak } \\
\hline 1 & Mujirah & 35 & Keong Mas & Keong Mas & 100 & Sesuai \\
\hline 2 & $\begin{array}{l}\text { Kasan } \\
\text { Dimejo }\end{array}$ & 78 & Tugro & Tugro & 100 & Sesuai \\
\hline 3 & Saniem & 45 & Penggerek Batang & $\begin{array}{l}\text { Pengerek } \\
\text { Batang }\end{array}$ & 63 & Sesuai \\
\hline 4 & Nurjanah & 38 & Tugro & Tugro & 88 & Sesuai \\
\hline 5 & Paryanti & 38 & Walang Sangit & Walang Sangit & 100 & Sesuai \\
\hline 6 & Jemino & 75 & HDB & $\begin{array}{l}\text { Pengerek } \\
\text { Batang }\end{array}$ & 95 & Tidak Sesuai \\
\hline 7 & Pawiro Loso & 77 & Keong Mas & $\begin{array}{l}\text { Tikus Sawah } \\
\text { Keong Mas }\end{array}$ & 100 & Tidak Sesuai \\
\hline 8 & Parjio & 37 & Wereng & Wereng & 100 & Sesuai \\
\hline 9 & Poniman & 41 & Walang Sangit & Walang Sangit & 100 & Sesuai \\
\hline 10 & Ngadiman & 41 & Tikus Sawah & Tikus Sawah & 100 & Sesuai \\
\hline 11 & Tukiyo & 90 & Tugro & Tugro & 88 & Sesuai \\
\hline 12 & Wakir & 65 & Tugro & Tugro & 88 & Sesuai \\
\hline
\end{tabular}




\begin{tabular}{|l|l|l|l|l|c|l|}
\hline NO & \multicolumn{1}{|c|}{ Nama } & Umur & Hasil Pakar & Hasil Sistem & $\mathbf{\%}$ & Sesuai/Tidak \\
\hline 13 & Joyo Ngadiyo & 75 & Wereng & Wereng & 100 & Sesuai \\
\hline 14 & Jirah & 60 & Tugro & Tugro & 100 & Sesuai \\
\hline 15 & Watini & 49 & HBD & $\begin{array}{l}\text { Pengerek } \\
\text { Batang }\end{array}$ & 95 & Tidak Sesuai \\
\hline 16 & Sajiman & 55 & HBD & HBD & 100 & Sesuai \\
\hline 17 & Kliyem & 55 & Wereng & Wereng & 100 & Sesuai \\
\hline 18 & Paidin & 45 & Wereng & Wereng & 100 & Sesuai \\
\hline 19 & Sutiman & 35 & Tikus Sawah & Tikus Sawah & 100 & Sesuai \\
\hline 20 & Remo & 43 & Keong Mas & Keong Mas & 86 & Sesuai \\
\hline
\end{tabular}

Berdasarkan 20 data yang didapatkan diuji terhadap pakar dan sistem dengan keseuaian presentase $85 \%$ dan yang tidak sesuai dengan sistem adalah $15 \%$.

Besarnya presentase berdasarkan hasil hitung tiap gejala terhadap hama padi dapat dilihat pada tabel berikut :

Tabel 7. Hasil Validasi Data

\begin{tabular}{|l|l|l|}
\hline \multicolumn{1}{|c|}{ Ket Validasi Sistem } & \multicolumn{1}{c|}{ Jumlah } & \multicolumn{1}{c|}{ Presentase } \\
\hline Sesuai & 17 & 85 \\
\hline Tidak Sesuai & 3 & 15 \\
\hline Total & 100 \\
\hline
\end{tabular}

\section{KESIMPULAN}

Dari penelitian yang dilakukan, kesimpulan yang diperoleh adalah sebagai berikut:

1. Berdasarkan 20 data yang telah diujikan terhadap pakar dan sistem, untuk tingkat kesesuaian berdasarkan hasil validasi pakar dan sistem, diperoleh dengan persentase sebesar $85 \%$ data kasus yang sesuai, serta $15 \%$ data kasus yang tidak sesuai.

2. Sistem dirancang dengan mengimplementasikan metode teorema bayes dan forward cahining dapat digunakan untuk membantu dalam identifikasi hama padi dan penanganannya.

\section{DAFTAR PUSTAKA}

Amborowati, A., \& Hidayah, N. (2016). Analisis Dan Perancangan Sistem Pakar Diagnosa Penyakit Mematikan Pada Perempuan Menggunakan Metode Bayes (Studi Kasus : Asri Medical Center). Seminar Nasional Teknologi Informasi dan Multimedia 2016, ISSN : 2302-3805.

Anggara, G., Pramayu, G., \& Wicaksana, A. (2016). Membangun Sismtem Pakar Menggunakan Teorema Bayes Untuk Mendiagnosa Penyakit Paru-Paru. Seminar Nasional Teknologi Informasi dan Multimedia 2016, ISSN : 23023805. 
Dewi, P. S., Ryana, L. D., \& Lestari, R. T. (2015). Model Sistem Pakar Diagnosa Hama Tanaman Padi Untuk Memberikan Solusi Penanggulangan. Jurnal Ilmiah Komputer dan Informatika (KOMPUTA), ISSN:2089-9033, 25-35.

Irawan, N. (2016). Aplikasi Sistem Pakar Identifikasi Penyakit Pada Tanaman Padi Menggunakan Metode Certainty Factor. Malang: Universitas Islam Negeri Maulana Malik Ibrahim.

Irsan, M., Pratama , V. N., \& Fakih , M. (2015). Sistem Pakar Identifikasi Penyakit Tanaman Padi Di Balai Penyuluhan Pertanian Sepatan Tangerang . Konferensi Nasional Sistem \& Informatika 2015, 284-289.

Pratama, A. N., \& Sukandi. (2013). Sistem Pakar Untuk Mendiagnosis Hama Dan Penyakit Tanaman Padi. Indonesian Jurnal on Computer Science ISSN : 1979-9330, 74-82.

Rosnelly, R. (2012). Sistem Pakar Konsep dan Teori. Yogyakarta: Andi.

Usman, A. (2005). Pengolahan Citra Digital \& Teknik Pemrogramannya. Yogyakarta: Penerbit Graha Ilmu.

Yulianto, Setiadi, A., Firmansyah, I., Maulana, I., Asmoro, D., \& Kamal, H. (2015). Model Sistem Pakar Diagnosa Hama Tanaman Padi Untuk Memberikan Solusi Penanggulangan. Seminar Nasional Teknologi Informasi dan Multimedia 2015: ISSN : 2302-3805, 1-5 